\title{
Assessment of the egg parasitoid guild of rice leaf folder, Cnaphalocrocis medinalis (Guenee): a search for biocontrol agents
}

\author{
K.S. Hemachandra ${ }^{1 *}$ and M.C.D. Perera ${ }^{2}$ \\ ${ }^{\prime}$ Department of Agricultural Biology, Faculty of Agriculture, University of Peradeniya, Peradeniya. \\ ${ }^{2}$ Postgraduate Institute of Agriculture, University of Peradeniya, Peradeniya.
}

Revised: 23 July 2015; Accepted: 23 September 2015

\begin{abstract}
Biological control of rice leaf folder (RLF), Cnaphlocrocis medinalis by augmentative release of egg parasitoids has been suggested. This study was conducted to assess the egg parasitoid guild associated with the RLF and to determine their parasitism levels under local conditions. A survey was conducted in three districts at 14 sites using 16 fields where rice was cultivated under conventional, pesticide free and organic farming practices. RLF eggs were collected and incubated at room temperature with $60 \%$ $\mathrm{RH}$ under natural daylight in the laboratory. The emerging parasitoids were identified and their parasitism levels were calculated.

Four egg parasitoid species: Troichogrammatoidea bactrae, Troichogrammatoidea nana, Trichogramma sp. and Lithromeromyia sp. (Hymenoptera: Trichogrammatidae) were found parasitising RLF eggs. These species collectively parasitised $17 \%$ of RLF eggs and the level of parasitism significantly varied between 0 and $57 \%$ among sampling sites. Mean parasitism in conventional and pesticide free fields were $1.62 \pm 0.81 \%$ and $24.39 \pm 16.8 \%$, respectively, which was significantly different. T. bactrae was the most prevalent parasitoid species, which was found in nine sites, while T. nana and Lithromeromyia sp. were found only in one site. Trichogramma sp. was found in four sites. Mean parasitism caused by $T$. bactrae, T. nana, Trichogramma sp. and Lithromeromyia sp. were $8.2 \pm 5.7 \%, 15.2 \%, 3.7 \pm$ $1.3 \%$ and $2.5 \%$, respectively. The parasitoids did not affect beneficial arthropods such as spiders and coccinellids. The results suggest that $T$. bactrae is a potential egg parasitoid of RLF to manage RLF populations in local rice fields through augmentative release.
\end{abstract}

Keywords: Cnaphalocrocis medinalis, egg parasitoids, Sri Lanka, Trichogrammatidae, Trichogrammatoidea bactrae.

\section{INTRODUCTION}

Rice leaf folder (RLF), Cnaphalocrocis medinalis (Guenee) (Lepidoptera, Pyralidae) is considered as one of the major defoliating insects damaging the rice crop (DOA, 2006) in all rice growing areas of Sri Lanka (Wickramasinghe, 1980). RLF adults lay eggs either singly or in pairs on the leaf blades of the rice plant and the incubation period is four days (Ranasinghe, 1992). There are five larval instars in the life history of the RLF and the larvae fold the edges of a leaf and construct a leaf roll. They live inside the rolled leaf feeding on the mesophyll cells of the leaf blades. The damage caused by the RLF larvae affects the growth of the plant leading to subsequent microbial infections (Pathak \& Khan, 1994). Yield loss associated with RLF damage has been estimated as $10 \%$ depending on the level and time of attack (Mikuriya et al., 1988). However, some studies have suggested that the yield reduction associated with RLF infestation is minimal (Asghar et al., 2009; Perera \& Hemachandra, 2013). In Sri Lanka, $10 \%$ of rice crop is affected annually by the RLF (Nugaliyadde et al., 2001).

Several methods have been established to manage the RLF (Pathak \& Khan, 1994). Chemical control is the conventional and commonly used method for RLF control. The Department of Agriculture of Sri Lanka has recommended several insecticides for managing RLF 
such as Fipronil $50 \mathrm{~g} / \mathrm{L} \mathrm{SC}$, Tebufenozide $200 \mathrm{~g} / \mathrm{L} \mathrm{SC}$, Methoxyfenozide $240 \mathrm{~g} / \mathrm{L} \mathrm{SC}$ etc. (DOA, 2010). However, negative impacts of insecticide application such as the destruction of beneficial natural enemies, environmental pollution, health hazards through occupational exposure, chronic ailments and increasing cost of paddy production are well established (Koul \& Cuperus, 2007). Hence, there is a need to find alternate methods of RLF control such as host plant resistance (HPR) or biological control. The method of HPR has been tried (Henrichs et al., 1985), but only a few rice varieties are available with adequate resistance against RLF.

Biological control of insect pests involves the use of entomopathogenic microbes such as Bacillus spp., Beveria bassiana and biocontrol agents such as parasitoids. Entomopathogenic microbes can be mass produced and sold as biopesticides (Sheng et al., 2002). However, the use of these biopesticides in tropical areas is still problematic due to strong sunlight and high temperatures. The impact of larval and pupal parasitoids on RLF is not adequate to control the pest, and other control strategies are needed because these parasitoids attack only the later stages of the RLF, and by that time the damage to the crop is extensive. Therefore, the use of larval and pupal parasitoids has not become popular (De Kraker, 1996).

The approach of releasing egg parasitoids has been successful and appears to be one of the potential strategies to manage RLF populations (Kumar \& Khan, 2005). This approach requires the identification of locally available egg parasitoids. In some countries, the egg parasitoid guild of RLF has been characterised (De Kraker et al., 1999). In Sri Lanka the larval and pupal parasitoids have been identified (Rajapakse, 1990) but there are no records of egg parasitoids of RLF. Trichogramma chilonis, Trichogramma closterae, Trichogramma confusum, Trichogramma dendrolimi, Trichogramma japonicum, Trichogramma leucaniae, Trichogramma ostriniae, Trichogrammatoidea nana and Trichogramma spp. have been recorded as egg parasitoids of RLF in India, The Philippines, Malaysia and China (Vreden \& Ahmadzabidi, 1986; Gurr et al., 2012).

This study was conducted with the following objectives. The assessment of the locally present egg parasitoid guild of RLF and assessment of the degree of parasitism by each species at different locations under two management practices: the conventional (with the use of pesticides) and pesticide free cultivation systems.

\section{METHODOLOGY}

This study was conducted during December 2011 - August 2013. The study had three major components: (a) field collection of parasitoid eggs, (b) laboratory rearing of collected eggs and (c) the identification of egg parasitoid adults.

\section{Field collection of parasitoid eggs}

Field collections were conducted in selected rice growing areas in Kandy, Kurunegala and Anuradhapura Districts. The selected fields had been cultivated under two cultivation systems: conventional and pesticide free. The selection of rice fields was done based on the presence of RLF infestation, convenient access for regular sampling and the history of pesticide usage.

Sixteen rice fields in 14 sites from 3 districts were selected for the study (Table 1). The number of samples collected from these fields varied from $1-30$ depending on the level of infestation and the logistics associated with visiting the fields. Some of the fields were visited at weekly intervals to collect RLF eggs.

During sampling, leaf blades and leaf sheaths of rice plants were examined using a hand lens. If RLF eggs were found, they were collected along with the leaf blade into a clean and clear plastic vial $(5.5 \mathrm{~cm}$ height and $2.5 \mathrm{~cm}$ diameter). The plastic vials with eggs were stored in a cool box and transported on the same day to the laboratory of the Department of Agricultural Biology, Faculty of Agriculture, University of Peradeniya.

During the collection, eggs of other beneficial insects like coccinellids, spiders and Andrallus spinidens were also collected using the above procedure.

\section{Laboratory rearing of egg parasitoids}

In the laboratory, the collected eggs were examined under the dissecting microscope (Meiji, Japan 1-7 × 10) for un-hatched eggs or egg masses and they were placed individually in clear plastic vials for incubation. In the case of egg masses where the eggs could not be separated, each egg mass was placed in clear plastic vials separately. Each vial was labelled with a code that was tagged with all collection details. The eggs were incubated at room temperature $\left(26 \pm 2{ }^{\circ} \mathrm{C}\right)$ and $60 \% \mathrm{RH}$ under natural daylight in the laboratory. Vials were examined daily for emergence of host larvae or egg parasitoid 
adults. Upon emergence of adult parasitoids, they were preserved in $70 \%$ ethanol in plastic vials separately with necessary information until further laboratory examination for identification. The identity of each and every parasitoid adult was determined and recorded.

\section{Identification of egg parasitoids}

Adult egg parasitoids were identified according to the protocol described by Noyes (2013). The male parasitoids were separated by the characteristics of the antennae. They were carefully mounted on cards and using external morphology, the different morphological species were identified.

Card mounted specimens were used for the preparation of glass slides by adopting the procedure described by Platner et al. (1999). The wings were separated and mounted in Canada balsam on glass slides. The remaining parts of the body were separated and boiled in $10 \% \mathrm{KOH}$ for $5 \mathrm{~min}$, washed and processed in ethanol series and clove oil. The dehydrated

Table 1: Sampling sites where rice leaf folder eggs were collected for assessment of egg parasitoid guild during 2011 - 2013

\begin{tabular}{|c|c|c|c|c|}
\hline Sampling sites & Latitude and longitude & Type of field & Sampling period & Surrounding of the sampling site \\
\hline Karangoda & $6^{0} 67^{\prime} \mathrm{N} 80^{0} 36^{\prime} \mathrm{E}$ & $\mathrm{C}$ & $23.12 .2011-03.02 .2012$ & $\begin{array}{l}\text { Field is surrounded by large perennial } \\
\text { plants, isolated field }\end{array}$ \\
\hline Dellabada & $6^{0} 65^{\prime} \mathrm{N} 80^{0} 37^{\prime} \mathrm{E}$ & $\mathrm{C}$ & $23.12 .2011-03.02 .2012$ & $\begin{array}{l}\text { One side of the field borders a main } \\
\text { road, and other three sides were } \\
\text { bordered by paddy fields }\end{array}$ \\
\hline Hindagala (3 sites) & $7^{0} 23^{\prime} \mathrm{N} 80^{\circ} 60^{\prime} \mathrm{E}$ & $\mathrm{C}$ & $16.01 .2012-26.12 .2012$ & $\begin{array}{l}\text { One side of the field borders a cassava } \\
\text { plantation and other three sides were } \\
\text { bordered by paddy fields }\end{array}$ \\
\hline Gelioya & $7^{0} 21^{\prime} \mathrm{N} 80^{0} 59^{\prime} \mathrm{E}$ & $\mathrm{C}$ & $03.01 .2012-10.02 .2012$ & $\begin{array}{l}\text { One side of the field borders a main } \\
\text { road, and other three sides were } \\
\text { bordered by paddy fields }\end{array}$ \\
\hline Ihalawela & $7^{0} 29^{\prime} \mathrm{N} 80^{\circ} 72^{\prime} \mathrm{E}$ & $\mathrm{PF}$ & $30.12 .2011-14.02 .2012$ & $\begin{array}{l}\text { Surrounded on all sides by paddy fields } \\
\text { that were managed by conventional } \\
\text { methods }\end{array}$ \\
\hline Bathalagoda & $7^{0} 48^{\prime} \mathrm{N} 80^{\circ} 36^{\prime} \mathrm{E}$ & $\mathrm{O}$ & 27.01 .2012 & $\begin{array}{l}\text { One side of field bordered by a conventional } \\
\text { rice field, and the other three sides by } \\
\text { organic fields. }\end{array}$ \\
\hline Bathalagoda & $7^{0} 48^{\prime} \mathrm{N} 80^{\circ} 36^{\prime} \mathrm{E}$ & $\mathrm{C}$ & $27.01 .2012-09.08 .2012$ & $\begin{array}{l}\text { One side of the field bordered by } \\
\text { a narrow road, and other three sides } \\
\text { bordered by conventional paddy fields. }\end{array}$ \\
\hline Mahailluppallama & $8^{0} 06^{\prime} \mathrm{N} 80^{0} 53^{\prime} \mathrm{E}$ & $\mathrm{C}$ & $28.02 .2012-18.03 .2013$ & $\begin{array}{l}\text { Surrounded by paddy fields managed } \\
\text { using conventional methods }\end{array}$ \\
\hline Pallealudeniya & $7^{0} 12^{\prime} \mathrm{N} 80^{0} 56^{\prime} \mathrm{E}$ & $\mathrm{C}$ & $28.06 .2012-30.07 .2012$ & $\begin{array}{l}\text { Surrounded by paddy fields managed } \\
\text { using conventional methods }\end{array}$ \\
\hline Megodakalugamuwa & $7^{0} 18^{\prime} \mathrm{N} 80^{0} 71^{\prime} \mathrm{E}$ & $\mathrm{C}$ & $07.06 .2012-24.07 .2012$ & $\begin{array}{l}\text { Surrounded by paddy fields managed } \\
\text { using conventional methods }\end{array}$ \\
\hline Penideniya & $7^{0} 25^{\prime} \mathrm{N} 80^{0} 58^{\prime} \mathrm{E}$ & $\mathrm{PF}$ & $07.09 .2012-11.10 .2012$ & $\begin{array}{l}\text { Pesticide free field surrounded by large } \\
\text { plants and vegetable plants }\end{array}$ \\
\hline Mawathagama & $7^{0} 43^{\prime} \mathrm{N} 80^{\circ} 44^{\prime} \mathrm{E}$ & $\mathrm{C}$ & 24.01 .2013 & $\begin{array}{l}\text { Surrounded by paddy fields managed } \\
\text { using conventional methods }\end{array}$ \\
\hline Ganegoda & $7^{0} 20^{\prime} \mathrm{N} 80^{\circ} 60^{\prime} \mathrm{E}$ & $\mathrm{C}$ & $06.02 .2013-21.03 .2013$ & $\begin{array}{l}\text { Surrounded by paddy fields managed } \\
\text { using conventional methods }\end{array}$ \\
\hline Wathurakumbura & $7^{0} 29^{\prime} \mathrm{N} 80^{0} 54^{\prime} \mathrm{E}$ & $\mathrm{PF}$ & $08.01 .2013-12.08 .2013$ & $\begin{array}{l}\text { Pesticide free paddy field surrounded by } \\
\text { banana trees and other large trees }\end{array}$ \\
\hline
\end{tabular}

C: Conventional fields; PF: Pesticide free fields; O: Organic field 
specimens were mounted in thin balsam on a glass slide under the dissecting microscope. The antennae, head capsule, wings, body and the genitalia were mounted separately in balsam and covered with $8 \mathrm{~mm}$ diameter cover glasses.

The prepared slides were kept at $35{ }^{\circ} \mathrm{C}$ in an oven for 10 days until the slides were well dried. The slides were examined under a compound light microscope $(40 \times 10)$ and the genitalia structure was compared with the sketches given in Trichogramma identification keys and the original descriptions, sketches given when first describing the species (Nagaraja, 1978). Confirmation of the species identity was made by Dr Andrew Polazeik, Natural History Museum, London, United Kingdom followed by molecular identification at the University of California, USA.

The degree of parasitism was estimated as the number of parasitoid adults that emerged divided by the total number of host eggs multiplied by 100 (Van Driesche, 1983). The data were analysed using Chi-square test in SYSTAT (version 11).

\section{RESULTS AND DISCUSSION}

A total of 13,733 eggs were collected from 161 samples in 16 fields. The number of eggs collected from each field significantly varied among the sampling fields $\left(\mathrm{X}^{2}=11997.5, \mathrm{df}=15, \mathrm{p}<0.001\right)$. The highest number of eggs was collected from the field at Penideniya, which had been maintained as a pesticide free field (Table 2). The lowest number of eggs was found in the Mawathagama field, which had been maintained using conventional methods. Generally, slightly more RLF eggs $(54.5 \%)$ were collected from conventionally managed fields compared to the pesticide free fields.

Four different species of egg parasitoids were identified. They were all Trichogrammatids (Hymenoptera, Chalcidoidea). The species were Trichogrammatoidea bactrae Nagaraja, Trichogrammatoidea nana Zehntner, Lathromeromyia sp. and Trichogramma sp. The identities of the first two species were confirmed by Dr A. Polazek, Natural History Museum, London, United Kingdom. According to the Universal Chalcidoidea database and the other records available, this is the first record of T. bactrae and T. nana in Sri Lanka. Lathromeromyia sp. was found only from the Mahailluppallama rice field located in the Dry Zone. This species had been found to attack hemipteran eggs in rice fields as well as in other fields (Yousuf \& Shafee, 1987).
According to previous studies, Trichogramma chilonis, T. closterae, T. confusum, T. dendrolimi, T. japonicum, T. leucaniae, T. ostriniae and Trichogrammatoidea nana have been reported as egg parasitoids of RLF (Vreden \& Ahmadzabidi, 1986; Gurr et al., 2012). Of these species, Trichogramma chilonis and Trichogramma japonicum (Bentur et al., 1994; Kumar \& Khan, 2005) have been found in Indian rice fields, which are similar to Sri Lankan rice fields.

The numbers of RLF eggs collected from conventional rice fields and pesticide free fields were significantly different $\left(\mathrm{X}^{2}=22.17\right.$, df $\left.=1, \mathrm{p}<0.001\right)$ and were associated with the level of RLF infestation, the number of samples and sampling durations. The total number of eggs collected from pesticide free fields was slightly lower than the number collected from conventional fields.

Out of the eggs collected in the fields, 2338 eggs were parasitised with the mean parasitism of $17.02 \%$. This finding agrees with a result of a similar study by De Kraker et al. (1999), in irrigated rice in the Laguna Province, the Philippines. The same study reported egg parasitism of C. medinalis by Trichogramma to be $0-27 \%$.

The total number of parasitised and unparasitised eggs significantly varied among sampling sites $\left(X^{2}=5585.47, \mathrm{df}\right.$ $=15, \mathrm{p}<0.001)$. The highest level of parasitism of RLF eggs by all egg parasitoid species was recorded in the Penideniya field, which was $57.29 \%$. Depending on the sampling sites, total parasitism of RLF eggs varied between 0 and $57 \%$ (Table 2). Except in the Penideniya field, parasitism in other fields varied between 0 and $14 \%$. The variation of the level of parasitism among the sites is possible as the level of parasitism depends on site characteristics such as the history of pesticide application, characteristics of surrounding fields, scale of farming in the area, rice variety, differences in the population size of the parasitoids, differences in the ability of parasitoids to find and parasitise their hosts, and differences in landscape structure etc. (Hunter, 2002). Geographical feature variation among the sites also has an influence on the variation of parasitism (Hunter, 2002). Exceptionally high level of parasitism in the Penideniya field might be associated with flowering vegetation and high number of plant species in the surrounding area. Parasitism of RLF eggs by T. nana (15\%) has contributed largely to the total parasitism, which was absent in other sampling sites. Stephens et al. (1998) have found higher parasitism rates in crops with nearby flowering vegetation. Weeds are beneficial to parasitoids as alternate hosts, complementary hosts, as a food source (pollen and nectar) or as resting sites for adults (Norris \& Kogan, 2000). 
The level of parasitism of RLF eggs by all egg parasitoid species in conventional fields, pesticide free fields and organic field were $1.62 \pm 0.81 \%, 24.39 \pm 16.8 \%$ and $0.68 \%$ respectively, which was significantly different $\left(\mathrm{X}^{2}=3212.57, \mathrm{df}=2, \mathrm{p}<0.001\right)$. It was expected to have a high level of parasitism in organically managed fields but it was not found to be so.

The organically managed field was under organic practices only for a short period of time (two years) and one side was bordered by a conventional paddy field.
These factors might have influenced to produce a low level of parasitism in the organic field. The level of parasitism of RLF eggs by all egg parasitoids significantly varied between pesticide free and conventionally managed fields $\left(X^{2}=3104, d f=1, p<0.001\right)$. This reflects the impact of pesticides on the existence of egg parasitoids in the field, which agrees with the data from many similar studies (Buchori et al., 2010; Gnanakumar et al., 2012). Parasitoids usually have a very low survival if the environment is contaminated with pesticide residues (Norris \& Kogan, 2000).

Table 2: Parasitism of rice leaf folder eggs by different species of egg parasitoids in 16 different rice fields.

\begin{tabular}{|c|c|c|c|c|c|c|c|c|}
\hline \multirow[b]{2}{*}{ Location } & \multirow[b]{2}{*}{$\begin{array}{l}\text { No. of } \\
\text { samples }\end{array}$} & \multirow[b]{2}{*}{$\begin{array}{c}\text { No. of RLF } \\
\text { eggs collected }\end{array}$} & \multirow[b]{2}{*}{$\begin{array}{l}\text { No. of emerged } \\
\text { parasitoids }\end{array}$} & \multicolumn{5}{|c|}{ Parasitism (\%) } \\
\hline & & & & T. bactrae & T. nana & $\begin{array}{l}\text { Trichogra- } \\
\text { mma sp. }\end{array}$ & $\begin{array}{l}\text { Lathromer- } \\
\text { omyia } \mathrm{sp} \text {. }\end{array}$ & $\begin{array}{c}\text { Total } \\
\text { parasitism }(\%)\end{array}$ \\
\hline Karangoda & 6 & 555 & 0 & 0 & 0 & 0 & 0 & 0 \\
\hline Dellabada & 6 & 451 & 0 & 0 & 0 & 0 & 0 & 0 \\
\hline Hindagala-A & 14 & 707 & 16 & 2.26 & 0 & 0 & 0 & 2.26 \\
\hline Hindagala-B & 16 & 997 & 13 & 1.30 & 0 & 0 & 0 & 1.30 \\
\hline Hindagala-C & 18 & 913 & 2 & 0.22 & 0 & 0 & 0 & 0.22 \\
\hline Gelioya & 6 & 382 & 0 & 0 & 0 & 0 & 0 & 0 \\
\hline Ihalawela & 7 & 852 & 16 & 1.88 & 0 & 0 & 0 & 1.88 \\
\hline Bathalagoda & 1 & 293 & 2 & 0 & 0 & 0.68 & 0 & 0.68 \\
\hline Bathalagoda & 14 & 1175 & 0 & 0 & 0 & 0 & 0 & 0 \\
\hline Mahailluppallama & 3 & 376 & 26 & 2.23 & 0 & 2.50 & 2.50 & 6.91 \\
\hline Pallealudeniya & 5 & 346 & 0 & 0 & 0 & 0 & 0 & 0 \\
\hline Megodakalugamuwa & 30 & 1151 & 9 & 0.78 & 0 & 0 & 0 & 0.78 \\
\hline Penideniya & 16 & 3526 & 2020 & 53.76 & 15.15 & 0 & 0 & 57.29 \\
\hline Mawathagama & 1 & 147 & 0 & 0 & 0 & 0 & 0 & 0 \\
\hline Ganegoda & 4 & 289 & 23 & 2.91 & 0 & 5.33 & 0 & 7.96 \\
\hline Wathurakumbura & 14 & 1573 & 220 & 8.76 & 0 & 6.23 & 0 & 13.99 \\
\hline
\end{tabular}

Trichogrammatoidea bactrae was the most prevalent parasitoid species in all sampling sites. However, the parasitism level of RLF eggs by $T$. bactrae varied across sampling locations $\left(\mathrm{X}^{2}=2873, \mathrm{df}=15, \mathrm{p}<0.001\right)$. The highest level of parasitism by $T$. bactrae was $53.76 \%$ from the Penideniya field where exceptionally high level of parasitism was found. But in the other fields, it varied between 0 and $9 \%$. It is possible that one parasitoid species dominates a parasitoid guild due to its ability to better survive in the environment, a comparatively high efficiency in terms of host search behaviour and efficient parasitism (Hassell \& Waage, 1984; Getz \& Mills, 1996). The level of parasitism by $T$. bactrae significantly varied $\left(\mathrm{X}^{2}=1695.19, \mathrm{df}=1, \mathrm{p}<0.001\right)$ between pesticide free and conventional fields (Table 2 ) indicating better survival of T. bactrae in pesticide free fields, which agrees with a well documented study (Hafez et al., 1996). Considering the prevalence of T. bactrae in all fields where parasitism was reported, and the high survival in both types of fields, it is suggested that T. bactrae is a potential candidate for biological control of RLF.

Trichogrammatoidea nana was found only in the Penideniya rice field where the highest level $(15 \%)$ of parasitism of RLF eggs was reported. It appears that T. nana is not a widely distributed species. The host range of T. nana includes mainly lepidopteron insects such as Hypsiphyla sp. (Sands \& Murphy, 2001).

Trichogrammatoidea nana is capable of parasitising the eggs of Agryroploce schistocena, Bactra venosana, Chilo sacchariphagus, C. infuscatella, Corcyra cephalonica, Diatraea obliqua, Ephestia cautella, Eublemma amabilis, Hapalia macheralis, Holcocera 
pulverea, Hyblea puera, Hypsipyla robusta, Chickrassia sp., Swietenia macrophylla, Sylepta derogata, Thosea assigna and Tarucas theophrastus (Kazmi \& Chauhan, 2003). Considering the host range of T. nana, it is possible that the RLF might not be a preferred host or the rice ecosystem might not be a preferred habitat.

Trichogramma spp. was found in four sampling sites (Table 2) in Kandy, Kurunegala and Anuradhapura Districts and the level of parasitism of RLF eggs varied between 0.68 and $6.2 \%$. The level of parasitism significantly varied among the four sampling sites $\left(\mathrm{X}^{2}=78.4, \mathrm{df}=3, \mathrm{p}<0.001\right)$ (Table 2). These four sampling sites had been managed under conventional farming, pesticide free and organic practices and the level of parasitism significantly varied among the three management methods $\left(\mathrm{X}^{2}=52.1, \mathrm{df}=2, \mathrm{p}<0.001\right)$; the parasitism levels were $1.3,5.2$ and $0.7 \%$, respectively. However, it should be noted that the parasitism in the organic field is based on one sample with 293 RLF eggs.

Table 3: Parasitism of eggs of natural enemies of rice pests in sixteen different rice fields in three geographical zones

\begin{tabular}{lcccc}
\hline Location & $\begin{array}{c}\text { No. of } \\
\text { samples }\end{array}$ & Host species & $\begin{array}{c}\text { No. of host } \\
\text { eggs collected }\end{array}$ & $\begin{array}{c}\text { No. of emerged } \\
\text { parasitoids }\end{array}$ \\
\hline Karangoda & 6 & Spider eggs & 31 & 0 \\
Dellabada & 6 & Spider eggs & 23 & 0 \\
Hindagala-A & 14 & Spider eggs & 31 & 0 \\
Hindagala-B & 16 & Spider eggs & 48 & 12 \\
Hindagala-C & 18 & Spider eggs & 37 & 0 \\
Gelioya & 6 & Spider eggs & 21 & 0 \\
Ihalawela & 7 & Spider eggs & 49 & 0 \\
Bathalagoda & 15 & Spider eggs & 32 & 0 \\
Mahailluppallama & 3 & Spider eggs & 28 & 37 \\
& & Coccinellid sp. & 15 & 0 \\
Pallealudeniya & & Andrallus spinidens (F.) & 40 & 5 \\
Megodakalugamuwa & 5 & Spider eggs & 8 & 0 \\
Penideniya & 30 & Spider eggs & 11 & 0 \\
& 16 & Spider eggs & 104 & 31 \\
Mawathagama & & Coccinelid sp. & 20 & 0 \\
Ganegoda & 1 & Spider eggs & 3 & 0 \\
Wathurakumbura & 4 & Spider eggs & 28 & 4 \\
& 14 & Spider eggs & 105 & 23 \\
\hline
\end{tabular}

Lathromeromyia sp. was found in the Mahailluppallama rice field parasitising RLF eggs, which was based on two samples with nine parasitised eggs out of 362 RLF eggs. Lathromeromyia sp. generally parasitise the hemipteran eggs, but not lepidopteran eggs.

The non target effect of egg parasitoids was assessed by taking samples of eggs of naturally prevailing natural enemies (Table 3). Eggs of coccinellid species, predatory bug (Andrallus spinidens) and spider species are commonly found in the rice ecosystem. The egg masses of natural enemies had been parasitised in collections made in five locations (Table 3); however, the emerged parasitoids were not Trichogramma or Trichogrammatoidea species. This suggest that augmentation and release of Trichogramma or Trichogrammatoidea egg parasitoid species has no effect on naturally existing common natural enemies in the rice ecosystem as per the data in this study. It further confirms the suitability of egg parasitoids (Trichogramma or Trichogrammatoidea) as biocontrol agents to use in augmentation and release programmes in managing RLF control in Sri Lankan rice fields.

\section{CONCLUSION}

The findings are valuable to promote $T$. bactrae as a biocontrol agent to manage RLF.

\section{Acknowledgement}

Financial support received through The National Research Council, Sri Lanka (Grant no. 11-116) is greatly appreciated. 


\section{REFERENCES}

1. Asghar M., Suhail A., Afzal M. \& Khan M.A. (2009). Determination of economics threshold levels for the stem borers (Scirpophaga sp.) and leaf folder (Cnaphalocrocis medinalis) of rice (Oryza sativa) in the Kallar tract of Punjab, Pakistan. International Journal of Agricultural Biology 11: 717 - 720 .

2. Bentur J.S., Kalode M.B., Rajendran B. \& Patel V.S. (1994). Field evaluation of the egg parasitoid, Trichogramma japonicum Ash. (Hym., Trichogrammatidae) against the rice leaf folder, Cnaphalocrocis medinalis (Guen.) (Lep., Pyralidae) in India. Journal of Applied Entomology 117: $257-261$.

DOI: http://dx.doi.org/10.1111/j.1439-0418.1994.tb00733.x

3. Buchori D., Meilin A., Hidayat P. \& Sahari B. (2010). Species distribution of Trichogramma and Trichogrammatoidea genera (Trichogrammatoidea: Hymenoptera) in Java. Journal of International Society for Southeast Asian Agricultural Science 16(1): 83 - 96.

4. De Kraker J. (1996). The potential of natural enemies to suppress rice leaf folder populations. PhD thesis, Land Boureniver Siteit Wageminger, The Netherlands.

5. De Kraker J., van Huis A., Heong K.L., van Lenteren J.C. \& Rabbinge R. (1999). Population dynamics of rice leaf folders (Lepidoptera: Pyralidae) and their natural enemies in irrigated rice in the Philippines. Bulletin of Entomological Research 89: $411-421$.

DOI: http://dx.doi.org/10.1017/S0007485399000541

6. Department of Agriculture (DOA) (2006). Insect Pest Management. Available at http://www. agridept.gov.lk/ index.php/en/crop recommendations/902, Accessed 12 September 2013.

7. Department of Agriculture (DOA) (2010). Pesticide Recommendations. Department of Agriculture, Peradeniya.

8. Getz W.M. \& Mills N.J. (1996). Host parasitoid coexistence and egg limited encounter rates. The American Naturalist 148: $333-347$.

DOI: http://dx.doi.org/10.1086/285928

9. Gnanakumar M., Rajmohana K., Bijoy C., Balan D. \& Nishi R. (2012). Diversity of hymenopteran egg parasitoids in organic and conventional paddy ecosystems. Tropical Agricultural Research 23(4): 300 - 308.

DOI: http://dx.doi.org/10.4038/tar.v23i4.4865

10. Gurr G.M., Read D.M.Y., Catindig J.L.A., Liu J.C.J.L., Lan L.P. \& Heong K.L. (2012). Parasitoids of the rice leaf folder Cnaphalocrocis medinalis and prospects for enhancing biological control with nectar plants. Agricultural and Forest Entomology 14: 1 - 12.

DOI: http://dx.doi.org/10.1111/j.1461-9563.2011.00550.x

11. Hafez A.A.E., Moawad G.M., El-Gemeiy H.M. \& Rashad A.M. (1996). Effect of some insecticides on Trichogramma evanescens Westwood, Trichogrammatoidea bactrae Nagaraja, and hatchability of Pectinophora gossypiella (Saund.) eggs. Egyptian Journal of Biological Pest Control 6: 1.
12. Hassell M.P. \& Waage J.K. (1984). Host-parasitoid population interactions. Annual Review of Entomology 29: $89-114$.

DOI: http://dx.doi.org/10.1146/annurev.en.29.010184.000513

13. Henrichs E.A., Camanag E. \& Romena A. (1985). Evolution of rice cultivar for resistance to the leaf roller Cnaphocrocis medinalis (Lepidoptera: Pyralidae). Journal of Economic Entomology 78: 274 - 278.

DOI: http://dx.doi.org/10.1093/jee/78.1.274

14. Hunter M.D. (2002). Landscape structure, habitat fragmentation, and the ecology of insects. Agriculture and Forest Entomology 4: 159 - 166.

DOI: http://dx.doi.org/10.1046/j.1461-9563.2002.00152.x

15. Kazmi S.I. \& Chauhan N. (2003). Chalcidoid parasitoids (Hymenoptera: Chalcidoidea) of Hypsipyla robusta (Lepidoptera: Pyralidae), a pest of cedars and mahogany. Oriental Insects 37: $261-275$.

DOI: http://dx.doi.org/10.1080/00305316.2003.10417347

16. Koul O. \& Cuperus G.E. (2007). Ecologically Based Integrated Pest Management. CABI Publishing, London, UK.

DOI: http://dx.doi.org/10.1079/9781845930646.0000

17. Kumar S. \& Khan M.A. (2005). Bio-efficacy of Trichogramma spp. against yellow stem borer and leaf folder in rice ecosystem. Annals of Plant Protection Sciences 13: 97 - 99.

18. Mikuriya H., Kuchiki F. \& Yamaguchi J. (1988). Yield decrease of rice plants by injurious insects in Saga prefecture. II. yield loss caused by the rice leaf folder, Cnaphalocrocis medinalis Guenee in late rice varieties. Proceedings of the Association for Plant Protection of Kyushu 34: 103 - 105.

19. Nagaraja H. (1978). Studies on Trichogramma (Hymenoptera: Trichogrammatidae). Oriental Insects 12(4): 489 - 530 .

DOI: http://dx.doi.org/10.1080/00305316.1978.10432534

20. Norris R.F. \& Kogan M. (2000). Interactions between weeds, arthropod pests, and their natural enemies in managed ecosystems. Weed Science 48: $94-158$.

DOI:http://dx.doi.org/10.1614/0043-1745(2000)048[0094: IBWAPA]2.0.CO;2

21. Noyes J.S. (2013). Universal Chalcidoidea Database. World Wide Web electronic publication. Available at http:// www.nhm.ac.uk/chalcidoids, Accessed 05 January 2015.

22. Nugaliyadde L., Ahangama D., Jayathilake K., Wickramasinghe S. \& Hidaka T. (2001). Efficacy of insecticide used for rice leaf folder management in Sri Lanka. Annals of the Sri Lanka Development of Agriculture 3: 177 - 184.

23. Pathak M.D. \& Khan Z.R. (1994). Insect Pests of Rice. International Rice Research Institute, Los Banos, The Philippines.

24. Perera M.C.D. \& Hemachandra K.S. (2013). Studies on rice leaf folder, Cnaphalocrocis medinalis: Oviposition pattern and leaf damage \& yield relationship. Proceedings of the Sri Lanka Association for the Advancement of Science, 
2-6 December. University of Kelaniya, Kelaniya, Sri Lanka, 69: 25.

25. Platner G.R.R.K., Velten M., Planoutene M. \& Pinto J.D. (1999). Slide mounting techniques for Trichogramma (Trichogrammatidae) and other minute parasitic Hymenoptera. Entomological News 110(1): 56 - 64.

26. Rajapakse R.H.S. (1990). Impact of native parasitoids on rice leaf folder Cnaphalocrocis medinalis Guenee (Pyralidae: Lepidoptera) in southern Sri Lanka. Entomon 15: 207 - 212.

27. Ranasinghe M.A.S.K. (1992). Paddy Pests in Sri Lanka, pp. 43 - 44. Natural Resource Energy and Science Authority, 47/5, Maitland Place, Colombo 07, Sri Lanka.

28. Sands D.P.A. \& Murphy S.T. (2001). Prospects for biological control of Hypsipyla spp. with insect agents. In: Hypsipyla shoot borers in Meliaceae. Proceedings of an International Workshop Held at Kandy, Sri Lanka (eds. R.R. Floyd \& C. Hauxwell), 20 - 23 August 1996. Australian Centre for International Agricultural Research (ACIAR), Canberra, Australia, pp. $121-130$.

29. Sheng W.H., Ming X.Z. \& Nanhai Z. (2002). Control effects of compound of Bacillus thuringiensis preparation and chemicals on Cnaphalocrocis medinalis. Southwest China Journal of Agricultural Sciences 15: $79-81$.

30. Stephens M.J., France C.M., Wratten S.D. \& Frampton C. (1998). Enhancing biological control of leaf rollers (Lepidoptera: Tortricidae) by sowing buckwheat (Fagopyrum esculentum) in an orchard. Biocontrol Science and Technology 8: $547-558$.

DOI: http://dx.doi.org/10.1080/09583159830063

31. Van Driesche R.G.V. (1983). Meaning of percent parasitism in studies of insect parasitoids. Environmental Entomology 12: $1611-1622$.

DOI: http://dx.doi.org/10.1093/ee/12.6.1611

32. Vreden G.V. \& Ahmadzabidi A.L. (1986). Pests of Rice and their Natural Enemies in Peninsular Malaysia. Centre for Agricultural Publishing and Documentation, Wageningen, The Netherlands.

33. Wickramasinghe N. (1980). Fifteen years of progress in rice pest management research. Proceedings of the Rice Symposium, Colombo, Sri Lanka, pp. $49-76$.

34. Yousuf M. \& Shafee S.A. (1987). Taxonomy of Indian Trichogrammatidae (Hymenoptera: Chalcidoidea). Indian Journal of Systematic Entomology 4(2): 55 - 200. 